\title{
Taxonomy of the Genus Veillonella Prévot
}

\author{
T. D. MAYS,${ }^{1}$ L. V. HOLDEMAN,${ }^{1}$ W. E. C. MOORE, ${ }^{1}$ M. ROGOSA ${ }^{2}$ AND J. L. JOHNSON ${ }^{1}$ \\ Department of Anaerobic Microbiology, Virginia Polytechnic Institute and State University, Blacksburg, \\ Virginia 24061, ${ }^{1}$ and Microbial Systematics Section, National Institute of Dental Research, Bethesda, \\ Maryland $20205^{2}$
}

\begin{abstract}
Results of deoxyribonucleic acid homology studies of 116 strains of Veillonella Prévot, representing the two species and seven subspecies currently recognized in this genus, showed seven deoxyribonucleic acid homology groups distinct at the species level. Because the type strains of $V$. parvula subsp. parvula and $V$. alcalescens subsp. alcalescens had high homology, we regard $V$. alcalescens Prévot 1933 as a later subjective synonym of $V$. parvula (Veillon and Zuber, 1896) Prévot 1933. The species $V$. parvula, $V$. dispar (Rogosa) comb. nov., $V$. atypica (Rogosa) comb. nov., $V$. rodentium (Rogosa) comb. nov., $V$. ratti (Rogosa) comb. nov., $V$. criceti (Rogosa) comb. nov., and $V$. caviae sp. nov. (type strain, ATCC 33540 ) are recognized. Because most strains of $V$. criceti produced acid in peptone-yeast extract-fructose media, the genus description is emended to include strains that ferment fructose.
\end{abstract}

Organisms in the genus Veillonella Prévot are anaerobic, nonmotile, nonsporulating, small, gram-negative cocci arranged as diplococci, masses, and short chains. By electron microscopy, the basic arrangement appears to be diplococcal. Members of the genus generally do not attack carbohydrates but produce propionate and acetate from lactate, pyruvate, and peptones. The type species was first described by Veillon and Zuber (25) in 1898 and was designated Staphylococcus parvulus. The genus Veillonella, proposed in 1933 by Prévot (17), included small, anaerobic, gram-negative cocci occurring in irregular masses. Two species, $V$. parvula (Veillon and Zuber) Prévot and $V$. alcalescens (Prévot), were included.

The current taxonomy of Veillonella, most recently reviewed by Rogosa in 1964 (18), is based on the results of extensive cultural, nutritional, biochemical, and serological studies of a large number of isolates $(4,18,19,21-23)$. $V$. parvula, with three subspecies ( $V$. parvula subsp. parvula, $V$. parvula subsp. rodentium, and $V$. parvula subsp. atypica), and $V$. alcalescens, with four subspecies $(V$. alcalescens subsp. alcalescens, $V$. alcalescens subsp. ratti, $V$. alcalescens subsp. criceti, and $V$. alcalescens subsp. dispar), are currently recognized. The species and subspecies are differentiated serologically by whole-cell tube-agglutination reactions and on the basis of an absolute requirement for putrescine or cadaverine or of the decomposition of hydrogen peroxide by $V$. alcalescens, or both of the latter.

Preliminary deoxyribonucleic acid (DNA) homology results (T. D. Mays and J. L. Johnson,
Abstr. Annu. Meet. Am. Soc. Microbiol. 1977 I147, p. 179) showed that the type strains of the two species, $V$. parvula and $V$. alcalescens, had relatively high homology with each other and that some of the type strains of the various subspecies had little or no homology with each other or with the type strains of the species.

The purpose of this investigation was to ascertain the genetic groups of veillonellae by means of their DNA homologies. Many of the extant organisms investigated by Rogosa, strains from other culture collections, and some clinical isolates from the collection of the Department of Anaerobic Microbiology at Virginia Polytechnic Institute and State University (VPI) were included in the study.

\section{MATERIALS AND METHODS}

Bacterial strains. The Veillonella strains studied and their derivations and sources are listed in Table 1. Reference DNA for homology studies was prepared from the first strain listed in each group and from strain VPI 12134. Other strains are listed in order of decreasing homology values with the first strain of each group.

Biochemical reactions and growth requirements. Reduction of nitrate to nitrite, gas production, the $\mathrm{pH}$ of cultures in carbohydrate media, and volatile fatty acids produced in glucose, fructose, pyruvate, and lactate media were determined as described in the Anaerobe Laboratory Manual (5).

Requirements for putrescine, hypoxanthine, and vitamins were determined by serially transferring strains three or more times (or until there was no growth in fewer than three transfers) in $3 \mathrm{ml}$ of prereduced Casamino Acids-lactate (CL) broth and in CL broth supplemented with combinations of putrescine, hypoxanthine, and vitamins. CL broth contained 
TABLE 1 . Strains used in this study

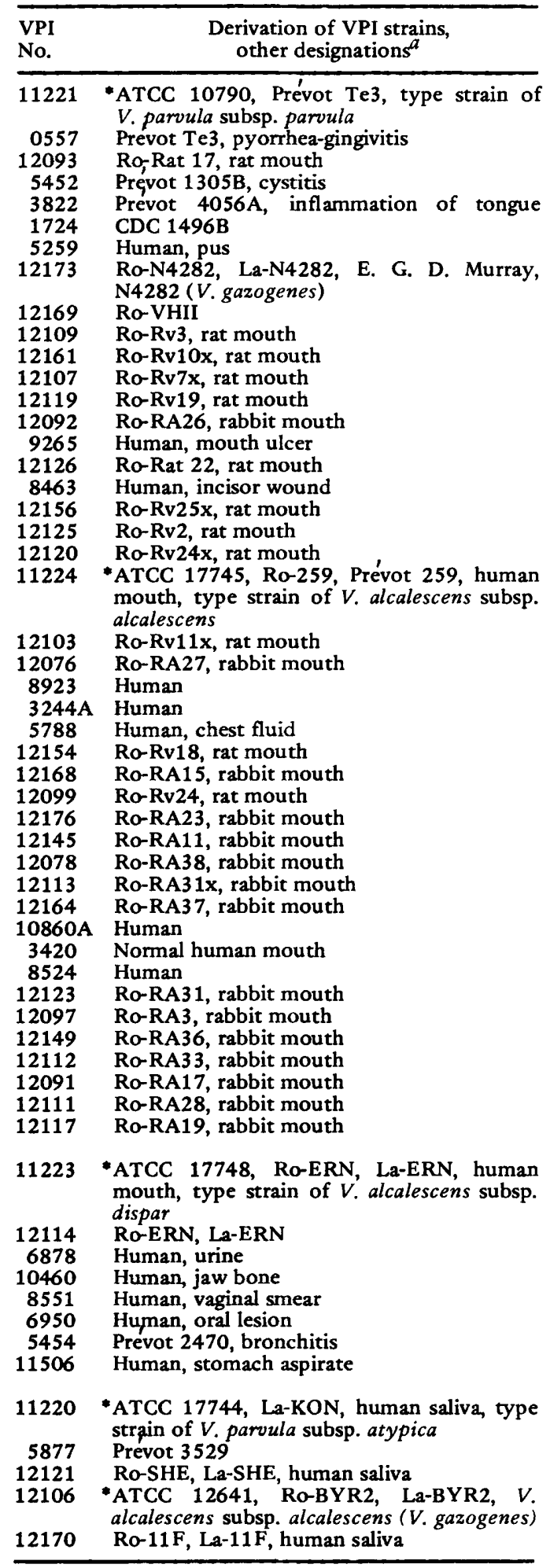

TABLE 1. Continued

\begin{tabular}{lc}
\hline $\begin{array}{l}\text { VPI } \\
\text { No. }\end{array}$ & $\begin{array}{c}\text { Derivation of VPI strains, } \\
\text { other designations }\end{array}$ \\
\hline
\end{tabular}

12148 Ro-KON, La-KON, human saliva

12118 Ro-DOE, La-DOE, human saliva

12172 Ro-COR1, La-COR1, human saliva

12157 Ro-MIN1, La-MIN1, human saliva

12077 Ro-WAR, La-WAR, human saliva

12166 Ro-NEM, La-NEM, human saliva

12132 Ro-ECK, La-ECK, human saliva

12108 Ro-RAK, La-RAK, human saliva

12162 Ro-5, V. parvula

5456 Prevot 2402, bronchitis

12917 *ATCC 14894, H. C. Douglas, UW221; Foubert and Douglas, T-5; (Micrococcus

lactilyticus)

12177 Ro-LIT3, La-LIT3, human saliva

11560 Human, lung

5418 Prevot 3227

12165 Ro-DAY, La-DAY, human saliva

3821 Prevot 2842, bronchial sample

3885 Normal mouth

12105 Ro-Z24B, La-Z24B, E. G. D. Murray, Z24B

12916 *ATCC 12642, La-CLE, M. J. Pelczar, human saliva

12138 Ro-CAM1, La-CAM1, human saliva

12088 Ro-PRI, La-PRI, human saliva

5451 Prevot 1582, tonsillitis

12159 Human saliva

3240 Ro-FOS, La-FOS, human saliva

12102 Ro-L3, La-L3, human saliva

12134 Ro-PV4, guinea pig mouth

11222 *ATCC 17743, Ro-HV19, hamster mouth, type strain of $V$. parvula subsp. rodentium

12146 Ro-HV18, hamster mouth

12089 Ro-HV23, hamster mouth

12155 Ro-HV12, hamster mouth

11225

*ATCC 17746, Ro-Rv12x, rat mouth, type strain of $V$. alcalescens subsp. ratti

12147 Ro-Rv12x, rat mouth

11226 *ATCC 17747, Ro-HV1, hamster mouth, type strain of $V$. alcalescens subsp. criceti

12096 Ro-HV16, hamster mouth

12175 Ro-HV25, hamster mouth

12094 Ro-HV1, hamster mouth

12141 Ro-HV13, hamster mouth

12144 Ro-HV7, hamster mouth

12158 Ro-HV2, hamster mouth

12130 Ro-HV9, hamster mouth

12127 Ro-HV24, hamster mouth

12135 Ro-HV3x, hamster mouth

12101 Ro-HV5, hamster mouth

12083 Ro-HV8, hamster mouth

12085 Ro-HV20, hamster mouth

12131 Ro-HV6, hamster mouth

12174 Ro-HV10, hamster mouth

3312A Human, abdomen

6788D Human, blood

12140 Ro-PV1, guinea pig mouth 12104 Ro-PV2, guinea pig mouth 12086 Ro-PV6, guinea pig mouth 12151 Ro-PV4X, guinea pig mouth

12136 Ro-PV8, guinea pig mouth

12153 Ro-PV3, guinea pig mouth 12100 Ro-PV7, guinea pig mouth 
TABLE 1. Continued

\begin{tabular}{cl}
\hline $\begin{array}{l}\text { VPI } \\
\text { No. }\end{array}$ & \multicolumn{1}{c}{$\begin{array}{c}\text { Derivation of VPI strains, } \\
\text { other designations }\end{array}$} \\
\hline 8638 & Human, vagina \\
12095 & Ro-MV3, mouse mouth \\
7944 & Human, urine \\
$1148 B$ & Normal human feces \\
\hline
\end{tabular}

${ }^{a}$ The VPI strain tested was from the first derivation cited. Ro- $=$ Rogosa collection number; $\mathrm{La}^{-}=$ Langford et al. (13) strain number. ATCC strains are designated with an asterisk (*) for convenience of location in the table.

(per $100 \mathrm{ml}$ ): $0.5 \mathrm{~g}$ of Casamino Acids (Difco), $0.7 \mathrm{ml}$ of $85 \%$ lactic acid, $4 \mathrm{ml}$ of salts solution (5), $0.4 \mathrm{ml}$ of resazurin solution (5), and $0.05 \mathrm{~g}$ of cysteine $\mathrm{HCl}$; $\mathrm{pH}$ was adjusted to 7.0. Supplements were added to CL broth from filter-sterilized stock solutions. Putrescine stock solution was prepared by dissolving $45 \mathrm{mg}$ of putrescine in $20 \mathrm{ml}$ of ethanol and adding $80 \mathrm{ml}$ of distilled water. The final concentration of putrescine in the test medium was $0.45 \mathrm{mg} / 100 \mathrm{ml}$. Hypoxanthine solution consisted of $300 \mathrm{mg}$ of hypoxanthine mixed with $50 \mathrm{ml}$ of distilled water and dissolved by adding drops of $10 \mathrm{~N}$ sodium hydroxide while heating. The final concentration of hypoxanthine in the test medium was $6 \mathrm{mg} / 100 \mathrm{ml}$ of broth. Vitamin solution was prepared by adding $2 \mathrm{mg}$ of calcium pantothenate, 20 $\mathrm{mg}$ of pyridoxal $\mathrm{HCl}, 20 \mathrm{mg}$ of thiamine $\mathrm{HCl}, 2 \mathrm{mg}$ of niacin, $0.01 \mathrm{mg}$ of $p$-aminobenzoic acid, and $0.1 \mathrm{mg}$ of biotin to $10 \mathrm{ml}$ of ethanol in $40 \mathrm{ml}$ of distilled water acidified with 2 drops of concentrated hydrochloric acid; $0.01 \mathrm{ml}$ of vitamin solution was added per $\mathrm{ml}$ of test broth. Original inoculum for the serial transfers was $0.03 \mathrm{ml}$ from an overnight peptone-yeast extract (5) broth culture. Serial transfers were $0.03 \mathrm{ml}$ of inoculum from an overnight culture with at least $2+$ growth (moderate turbidity) or from a 36-h-old culture if growth was less than $2+$ in $18 \mathrm{~h}$.

Polyacrylamide gel electrophoresis of soluble proteins. Cultures grown for $18 \mathrm{~h}$ in $5 \mathrm{ml}$ of supplemented brain heart infusion broth (5) with $0.1 \%$ calcium carbonate were sedimented, and $0.08 \mathrm{ml}$ of $\mathrm{pH} 7.0$ tris(hydroxylmethyl)aminomethane-chloride buffer and $0.15 \mathrm{~g}$ of $74-$ to $110-\mu \mathrm{m}$-diameter glass beads were added to the cell pellet. The cells were disrupted by shaking for two 2-min periods (16). Broken-cell preparations were heated at $55^{\circ} \mathrm{C}$ for $5 \mathrm{~min}$. Cellular debris was sedimented by centrifugation, and one-third volume of powdered sucrose per volume of supernatant was added. Soluble proteins were separated by slab gel electrophoresis and stained as described previously (16).

DNA isolation. The test organisms were grown in a medium prepared as described previously (3); it contained mineral salts, $1 \%$ Trypticase, $0.5 \%$ yeast extract, $2 \%$ sodium lactate, $0.03 \%$ cysteine, $0.03 \%$ sodium formaldehyde sulfoxalate, and $0.05 \mathrm{M}$ potassium phosphate buffer (pH 7.0). Flasks containing 1 liter of medium were inoculated with $20 \mathrm{ml}$ of an overnight culture and incubated for 18 to $24 \mathrm{~h}$ at $37^{\circ} \mathrm{C}$.

The harvested cells were suspended in $0.15 \mathrm{M} \mathrm{NaCl}$ and $0.01 \mathrm{M}$ ethylenediaminetetraacetic acid salt solution ( $\mathrm{pH} \mathrm{8.0)}$ ), incubated with $50 \mu \mathrm{g}$ of pronase per $\mathrm{ml}$ at $50^{\circ} \mathrm{C}$ for $30 \mathrm{~min}$, and then lysed by adding $20 \%$ sodium dodecyl sulfate to a final concentration of $1 \%$. After a preliminary extraction with chromatographygrade liquid phenol, high-molecular-weight DNA (for in vitro labeling) was isolated by the method of Marmur (14). Other DNA preparations were isolated by a hydroxyapatite procedure (7). This procedure was slightly modified in that the lysate did not contain any sodium borate and contained $0.1 \mathrm{M}$ phosphate buffer (pH 6.8).

Guanine-plus-cytosine $(\mathrm{G}+\mathrm{C})$ content of DNA. Thermal melting points $\left(T_{m}\right)$ were used to determine the $\mathrm{G}+\mathrm{C}$ contents of the DNA preparations, with DNA from Escherichia coli b used as the standard $(9,15)$.

Preparation of labeled DNA. The high-molecularweight DNA (diluted to $200 \mu \mathrm{g} / \mathrm{ml}$ ) was nicked by incubating it for $1 \mathrm{~min}$ with $0.1 \mu \mathrm{g}$ of electrophoretically purified deoxyribonuclease per $\mathrm{ml}$. The deoxyribonuclease was then inactivated by heating at $65^{\circ} \mathrm{C}$ for 10 min. The nicked DNA $(10 \mu \mathrm{g})$ was labeled with $\left[{ }^{3} \mathrm{H}\right]$ thymidine-triphosphate by means of a nick translation method (1). The specific activity of the labeled DNA preparations was about $100,000 \mathrm{cpm} / \mu \mathrm{g}$.

DNA homology experiments. Homology experiments were done by a variation of the $\mathrm{S} 1$ nuclease procedure described by Crosa et al. $(2,10)$. The reassociation mixtures contained $10 \mu \mathrm{l}$ (ca. $0.025 \mu \mathrm{g}$ ) of labeled DNA, $50 \mu \mathrm{l}(30 \mu \mathrm{g})$ of unlabeled DNA, and $50 \mu \mathrm{l}$ of $0.88 \mathrm{M} \mathrm{NaCl}-10^{-3} \mathrm{M}$ 4-(2-hydroxyethyl)-1-piperazineethanesulfonic acid (HEPES) buffer (pH 7.0). Just prior to each experiment, the amount of labeled DNA needed for the experiment was denatured by heating in a boiling-water bath for $5 \mathrm{~min}$. The reaction vials were incubated for $16 \mathrm{~h}$ at $60^{\circ} \mathrm{C}$

The unlabeled DNA used was either denatured and fragmented homologous or heterologous bacterial DNA or native fragmented salmon sperm DNA. Reaction vials containing native salmon sperm DNA were used to measure the amount of self-renaturation of labeled DNA during the incubation period.

\section{RESULTS}

The results of the $\mathrm{G}+\mathrm{C}$ determinations and of the DNA experiments are listed in Table 2. The serological results in Table 2 were summarized in an earlier paper (19) and provided a major criterion used in the taxonomy of these organisms (20).

The moles percent $\mathrm{G}+\mathrm{C}$ values obtained with the strains in this study are consistently 2 to $3 \%$ lower than those reported for the respective type strains in the 8th edition of Bergey's Manual (20). Those values were determined by $\mathrm{CsCl}$ buoyant density centrifugation. Small differences in $\mathbf{G}+\mathbf{C}$ values obtained with buoyant density and $T_{m}$ methods are not uncommon.

The DNA homology values reported here were determined by the S1 nuclease method. It is often difficult to obtain precisely reproducible results with this method. For example, when several preparations of DNA from a single strain were compared with labeled DNA from that strain, results varied by 10 to $15 \%$. Probable reasons for this have been discussed previously (8). 
TABLE 2. Homology values of Veillonella strains

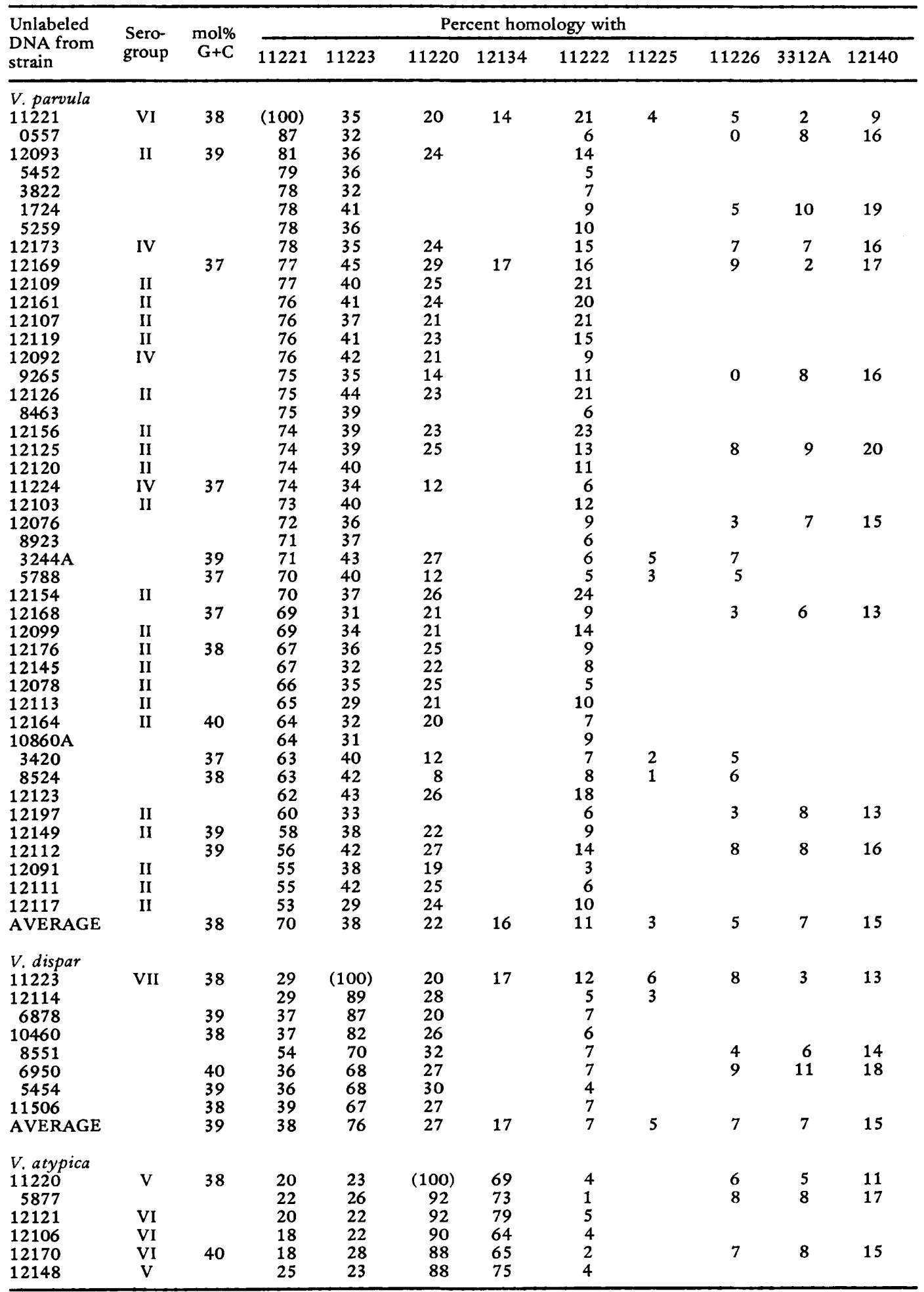


TABLE 2. Continued

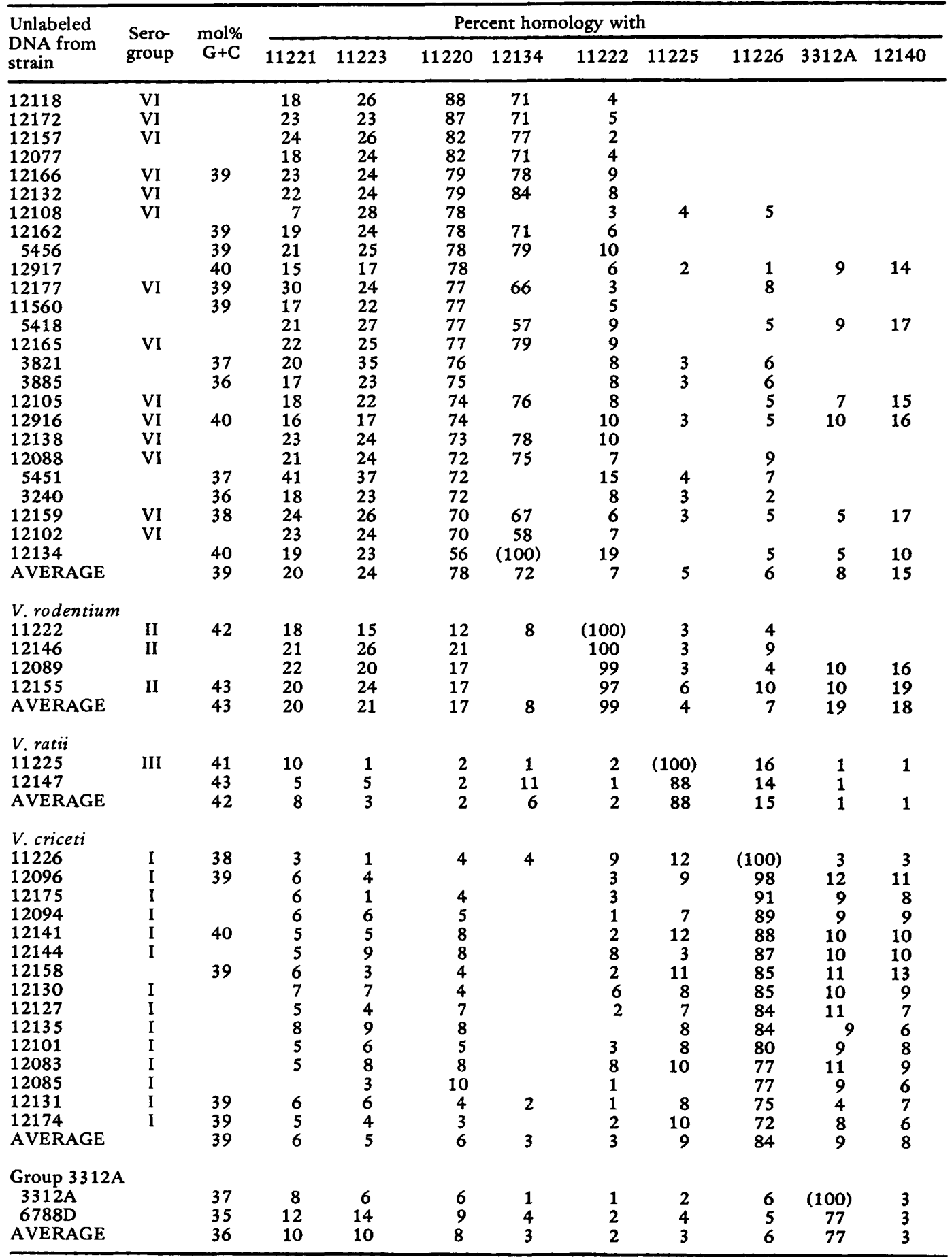


TABLE 2. Continued

\begin{tabular}{|c|c|c|c|c|c|c|c|c|c|c|c|}
\hline \multirow{2}{*}{$\begin{array}{l}\text { Unlabeled } \\
\text { DNA from } \\
\text { strain }\end{array}$} & \multirow{2}{*}{$\begin{array}{l}\text { Sero- } \\
\text { group }\end{array}$} & \multirow{2}{*}{$\underset{\mathrm{G}+\mathrm{C}}{\mathrm{mol} \%}$} & \multicolumn{9}{|c|}{ Percent homology with } \\
\hline & & & 11221 & 11223 & 11220 & 12134 & 11222 & 11225 & 11226 & $3312 \mathrm{~A}$ & 12140 \\
\hline $\begin{array}{l}V . \text { caviae sp. } \\
12140 \\
12104 \\
12086 \\
12151 \\
12136 \\
12153 \\
12100 \\
\text { AVERAGE }\end{array}$ & nov. & $\begin{array}{l}39 \\
38 \\
37 \\
39 \\
39 \\
39 \\
39\end{array}$ & $\begin{array}{l}17 \\
17 \\
13 \\
15 \\
15 \\
15 \\
16 \\
15\end{array}$ & $\begin{array}{l}16 \\
15 \\
16 \\
19 \\
14 \\
24 \\
18 \\
17\end{array}$ & $\begin{array}{l}21 \\
17 \\
19 \\
20 \\
19 \\
23 \\
22 \\
20\end{array}$ & $\begin{array}{r}12 \\
11 \\
11 \\
7 \\
11 \\
10\end{array}$ & $\begin{array}{r}21 \\
15 \\
6 \\
13 \\
6 \\
18 \\
18 \\
14\end{array}$ & $\begin{array}{l}2 \\
6 \\
4 \\
3 \\
7 \\
3 \\
2 \\
4\end{array}$ & $\begin{array}{r}9 \\
9 \\
2 \\
6 \\
6 \\
6 \\
10 \\
7\end{array}$ & $\begin{array}{r}11 \\
4 \\
10 \\
4 \\
3 \\
4 \\
5 \\
6\end{array}$ & $\begin{array}{c}(100) \\
97 \\
96 \\
92 \\
91 \\
75 \\
71 \\
87\end{array}$ \\
\hline $\begin{array}{l}\text { Other Veillo } \\
8638 \\
12095 \\
7944 \\
1148 \mathrm{~B}\end{array}$ & lla st & $\begin{array}{l}40 \\
41 \\
43\end{array}$ & $\begin{array}{r}15 \\
7 \\
6 \\
16\end{array}$ & $\begin{array}{r}9 \\
5 \\
11 \\
10\end{array}$ & $\begin{array}{l}2 \\
6 \\
7 \\
5\end{array}$ & $\begin{array}{r}0 \\
1 \\
13 \\
1\end{array}$ & $\begin{array}{l}2 \\
6 \\
9 \\
4\end{array}$ & $\begin{array}{r}1 \\
9 \\
29 \\
3\end{array}$ & $\begin{array}{l}3 \\
31 \\
16 \\
11\end{array}$ & $\begin{array}{r}1 \\
4 \\
10 \\
3\end{array}$ & $\begin{array}{r}6 \\
3 \\
10 \\
3\end{array}$ \\
\hline
\end{tabular}

The inherent variation of results with the S1 nuclease method probably explains the lack of $100 \%$ homology among cultures reputedly derived from the same strain (e.g., Prévot Te3, $V$. parvula subsp. parvula). DNA reference strain 11221 was obtained from the American Type Culture Collection (ATCC) strain 10790, deposited by J. E. Faber, who in turn received it from Prévot (Prévot Te3). Our strain 0557 is strain Te3 obtained directly from Prévot. DNA from strain 11221 had $87 \%$ homology with DNA from strain 0557. Similar results were obtained with other reference strains received from both the ATCC and the Rogosa collection. The solublecell-protein electrophoretic patterns (16) of these pairs of strains were identical, indicating that the pairs of strains may belong to the same strain. Although there can be slight differences among soluble-cell-protein electrophoretic patterns for different strains within a homology group, different cultures of the same strain usually give identical patterns (16).

The average $\mathrm{G}+\mathrm{C}$ values for the DNA preparations ranged from 36 to $43 \mathrm{~mol} \%$; the majority clustered around 39 mol\% (Table 2). The organisms were separable into eight DNA homology groups. Each group is designated by the VPI number of the reference strain for the group. The groups contained from one $(11225, \mathrm{~V}$. alcalescens subsp. ratti) to 44 representatives (11221, V. parvula subsp. parvula). There was 20 to $40 \%$ intergroup homology among strains in homology groups 11221,11223 , and $11220(\mathrm{~V}$. parvula subspp. parvula and atypica and $V$. alcalescens subsp. dispar). Strains in the 11220 group also were tested with a second reference strain, 12134, to see if there were subgroups within the group. No subgroups were indicated. The guinea pig isolates, represented by DNA reference strain 12140 , have 10 to $20 \%$ intergroup homology with the above-mentioned groups. The heterogeneity within the groups appears to vary. For example, organisms within the 11221 ( $V$. parvula subsp. parvula) DNA homology group have from 53 to $87 \%$ homology with the reference organism, whereas the organisms within the 11222 ( $V$. parvula subsp. rodentium) DNA homology group have 97 to $100 \%$ homology with the reference strain. The four "other Veillonella strains" (8638, 12095, 7944, and 1148B) listed in Table 2 have only low levels of DNA homology with any of the other reference strains.

All strains tested reduced nitrate to nitrite, did not ferment glucose, and produced hydrogen. Nine of 10 strains tested in the 11226 (V.alcalescens subsp. criceti) homology group lowered the $\mathrm{pH}$ of fructose medium by 0.4 to 1.0 (to $\mathrm{pH} 5.6$ or lower) and produced increased amounts of acetic and propionic acids. The other veillonellae did not ferment carbohydrates.

Some cultures required additional putrescine to produce sufficient cell yield for harvesting DNA from 1-liter cultures in Trypticase-yeast extract-lactate medium. This was most noticeable in strain 11224 (type strain of $V$. alcalescens subsp. alcalescens) and was consistent with the reported putrescine requirement by this subspecies. The putrescine, hypoxanthine, and vitamin requirements of 100 strains were tested. There was no clear requirement for putrescine, hypoxanthine, or vitamins among any of the homology groups, although these additives stimulated growth of many strains. The type strain of $V$. alcalescens subsp. alcalescens and 38 other strains that had high DNA homology with $V$. alcalescens subsp. parvula grew well in $\mathrm{CL}$ medium supplemented with putrescine, hypoxanthine, and vitamins, and in CL medium supplemented with hypoxanthine and vitamins (without putrescine). Vitamins or hypoxanthine stimulated growth of about half of the strains. 
There was no growth in CL without additives.

Polyacrylamide gel electrophoresis patterns for representatives of each of the homology groups are shown in Fig. 1.

\section{DISCUSSION}

Strains of Veillonella are exceedingly similar phenotypically. In general, they do not ferment the usual carbohydrates. Our preliminary studies of the fructose fermentation by some strains of $V$. alcalescens subsp. criceti suggest that this may be associated with the presence of a plasmid. In other rare instances $(11,12)$, ribose has been very weakly utilized for biosynthetic, nonfermentative purposes only. All strains in the genus similarly attack several metabolic intermediates (e.g., lactate and pyruvate). Crossreactions among some of the serological groups, particularly serogroups II, IV, V, and VI, have been reported (19). However, these low-titer cross-reactions were reciprocally absorbed (19), and serological groups were obtained with the absorbed antisera at high titers $(1: 2560$ to $1: 40,960$ ). Because serovars (serotypes) do not necessarily designate different species, the serovars were designated subspecies in two species. However, the separation of the species was difficult. The requirement for cadaverine or putrescine varied among strains in some of the

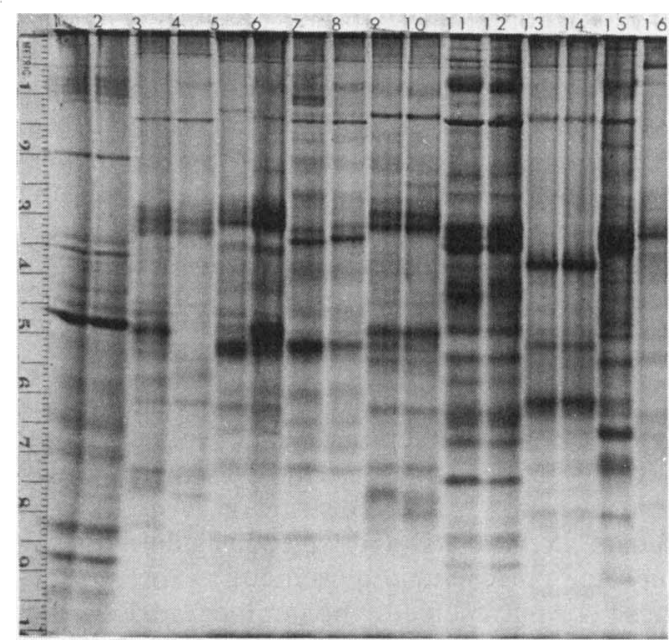

FIG. 1. Polyacrylamide gel electrophoretic patterns of soluble proteins from representative strains of Veillonella species. Lanes 1 and 2, Streptococcus faecalis standard reference strain U4-20. V. parvula: lane 3, ATCC 10790 (type); lane 4, VPI 12093. V. atypica: lane 5, ATCC 17744 (type); lane 6, VPI 12121. V. dispar: lane 7, ATCC 17748 (type); lane 8, VPI 6878. V. rodentium: lane 9, ATCC 17743 (type); lane 10, VPI 12146. V. criceti: lane 11, ATCC 17747 (type); lane 12, VPI 12096. V. caviae: lane 13, ATCC 33540 (type); lane 14, VPI 12104. V. ratti: lane 15, ATCC 17746 (type). Other veillonellae: lane 16 , human isolate VPI 3312A. subspecies (20). The decomposition of hydrogen peroxide often varied among subcultures of the same strain.

The results of this study demonstrate that the genus Veillonella consists of at least eight genetically distinct groups. Of the 116 strains of Veillonella tested, 112 showed a high level of DNA homology with one or another of eight reference strains. There was negligible or low intergroup homology, a result that indicates species-level differences (6). In general, the homology groups are represented by the type strains of the subspecies given in the 8th edition of Bergey's Manual (20). Two of the DNA homology groups, 12140 and 3312A, have not been recognized previously as distinct entities. The 12140 homology group consists of seven strains, all of which were isolated from the mouths of guinea pigs. These organisms appear to represent a major group of veillonellae isolated from the guinea pig, and therefore we are recognizing this group as a new species (see below). The 3312A homology group consisted of two human clinical isolates, one from urine and one from blood. Because there are only two strains in this group and strains of other groups appear to be much more commonly isolated from humans, we are deferring proposing a name for this group until additional strains are available for study. DNA from three other human strains (8638, vagina; 7944, urine; and 1148B, feces) and strain 12095 (mouse) had no homology with any of the reference DNA preparations used. These obviously represent other Veillonella species, but their importance cannot be ascertained at this time.

We propose that the former subspecies of $V$. parvula and $V$. alcalescens be elevated to species rank as V. parvula (Veillon and Zuber, 1898) Prévot, V. atypica (Rogosa) comb. nov., $V$. dispar (Rogosa) comb. nov., $V$. rodentium (Rogosa) comb. nov, , V. ratti (Rogosa) comb. nov., and $V$. criceti (Rogosa) comb. nov., and that the guinea pig isolates with significant homology with strain 12140 be named $V$. caviae sp. nov. with strain $12140(=$ ATCC 33540$)$ as the type strain. The type strain of $V$. parvula subsp. parvula had $74 \%$ homology with the type strain of $V$. alcalescens subsp. alcalescens; these are, therefore, the same species and are designated $V$. parvula by rule of priority. The relatedness of these two strains also has been indicated by Yoshimura et al. (26), who found that the acetate kinases from the two organisms have similar properties as measured by the effect of succinate on enzyme activity. Also, the purified enzymes gave serological cross-reactions and had similar electrophoretic migrations.

Sources of the strains of the species and the serogroups to which they belong, when known, are summarized in Table 3. 
TABLE 3. Type strains, sources, and serogroups of Veillonella species

\begin{tabular}{|c|c|c|c|c|c|c|c|c|c|c|}
\hline \multirow{2}{*}{ Species } & \multirow{2}{*}{$\begin{array}{l}\text { Type } \\
\text { strain }\end{array}$} & \multirow{2}{*}{$\begin{array}{l}\text { Isolated } \\
\text { from }\end{array}$} & \multicolumn{7}{|c|}{ Serogroup } & \multirow{2}{*}{$\begin{array}{l}\text { Serogroup } \\
\text { not tested }\end{array}$} \\
\hline & & & $\bar{I}$ & II & III & IV & $\mathrm{V}$ & $\overline{V I}$ & $\overline{\mathrm{VII}}$ & \\
\hline \multirow[t]{4}{*}{$V$. parvula } & ATCC 10790 & Human & - & - & - & $3^{a}$ & - & $1^{*}$ & - & 13 \\
\hline & & Rat & - & 12 & - & 1 & - & - & - & - \\
\hline & & Rabbit & - & 10 & - & - & - & - & - & 4 \\
\hline & & Unknown & - & - & - & 1 & - & - & - & 1 \\
\hline$V$. dispar & ATCC 17748 & Human & - & - & - & - & - & - & $1^{*}$ & 6 \\
\hline \multirow[t]{3}{*}{ V. atypica } & ATCC 17744 & Human & - & - & - & - & $1^{*}$ & 15 & - & 7 \\
\hline & & Guinea pig & - & - & - & - & - & - & - & 1 \\
\hline & & Unknown & - & - & - & - & - & 2 & - & 4 \\
\hline$V$. rodentium & ATCC 17743 & Hamster & - & $3^{*}$ & - & - & - & - & - & 1 \\
\hline V. rattii & ATCC 17746 & Rat & - & - & $1^{*}$ & - & - & - & - & 1 \\
\hline$V$. criceti & ATCC 17747 & Hamster & $14^{*}$ & - & - & - & - & - & - & 1 \\
\hline V. caviae & ATCC 33540 & Guinea pig & - & - & - & - & - & - & - & 7 \\
\hline
\end{tabular}

$a_{\text {Number of }}$ strains in serogroup; $-=$ no strains; ${ }^{*}=$ serogroup to which the type strain of the species belongs.

The description of the genus Veillonella presently states that carbohydrates and polyols are not fermented (20). Because fermentation of fructose occurs in some strains of $V$. criceti, the description of the genus is here emended.

Emendation of the description of the genus Veillonella. Carbohydrates and polyols are not fermented by most strains. Fructose fermentation has been observed with most strains of $V$. criceti.

Species and emendations of the descriptions of species in the genus. Veillonella parvula (Veillon and Zuber) Prévot 1933. Putrescine not required for growth in medium containing Casamino Acids, lactate, hypoxanthine, and vitamins. Strains are of human, rat, and rabbit origin. Most strains are from rats and rabbits and belong to serogroup II. Serogroups IV and VI are represented in the human strains. Type strain: ATCC 10790.

Veillonella dispar (Rogosa) comb. nov. (Basonym: $V$. alcalescens subsp. dispar Rogosa 1965, 708). Four of eight strains tested could be serially subcultured in a medium containing Casamino Acids, lactate, putrescine, hypoxanthine, and vitamins; four strains did not grow in the fourth serial transfer. Type strain: ATCC 17748 (24).

V. atypica (Rogosa) comb. nov. (V. parvula subsp. atypica Rogosa 1965, 707). Putrescine is not required for growth by the 29 strains tested in medium containing Casamino Acids, hypoxanthine, and vitamins. Isolated from the buccal cavity of man. Most strains belong to serogroup
VI; one strain belongs to serogroup V. Type strain: ATCC 17744 (24).

$V$. rodentium (Rogosa) comb. nov. (V. parvula subsp. rodentium Rogosa 1965, 707). Putrescine is not required for growth of the three strains tested in medium containing Casamino Acids, lactate, hypoxanthine, and vitamins. Vitamins were required by one of three strains tested. Isolated from the buccal cavity of the hamster. All strains tested belong to serogroup II. Type strain: ATCC 17743 (24).

$V$. ratti (Rogosa) comb. nov. ( $V$. alcalescens subsp. ratti Rogosa 1965, 708). The type strain grew in a medium containing Casamino Acids and lactate supplemented with either hypoxanthine and vitamins or putrescine and vitamins. Type strain: ATCC 17746 (24).

$V$. criceti (Rogosa) comb. nov. ( $V$. alcalescens subsp. criceti Rogosa 1965, 708). Only 3 of the 13 strains tested grew in a medium containing Casamino Acids, lactate, putrescine, hypoxanthine, and vitamins. Most strains fermented fructose. Type strain: ATCC 17747 (24).

$V$. caviae sp. nov. (M.L. noun Cavia genus of the guinea pig; M.L. gen. noun caviae of the guinea pig). Cells of the type strain and of six other strains tested are 0.2 to $0.3 \mu \mathrm{m}$ in diameter and are arranged in masses and pairs. Cells are gram negative, nonmotile, and nonsporeforming. Surface colonies on blood agar plates (brain heart infusion agar supplemented with yeast extract and 5\% defibrinated rabbit blood) are 1.0 to $2.0 \mathrm{~mm}$ in diameter, circular, and flat with an 
entire edge after $48 \mathrm{~h}$ at $37^{\circ} \mathrm{C}$ in an anaerobic atmosphere. No surface growth is obtained on similar blood agar plates incubated aerobically or in an atmosphere enriched to $10 \%$ with carbon dioxide.

Broth growth in prereduced peptone-yeast extract medium (5) is lightly turbid, usually without sediment in $24 \mathrm{~h}$. In peptone-yeast extract-lactate or peptone-yeast extract-pyruvate broths, growth is turbid, usually with a smooth sediment. Amygdalin, arabinose, cellobiose, erythritol, esculin, fructose, glucose, glycogen, inositol, lactose, maltose, mannitol, mannose, melezitose, melibiose, ribose, sorbitol, starch, sucrose, trehalose, and xylose are not fermented. Neither esculin nor starch is hydrolyzed. Indole is not produced. Nitrate is reduced to nitrite. Small to moderate amounts of acetate and propionate are detected in peptone-yeast extract cultures. Lactate and pyruvate are metabolized to acetate, propionate, hydrogen, and carbon dioxide. The type strain and six other strains tested grew well in a medium containing Casamino Acids, lactate, putrescine, hypoxanthine, and vitamins. Growth was not regularly obtained if any of these constituents was deleted from this medium.

Isolated from the mouths of guinea pigs.

The $\mathrm{G}+\mathrm{C}$ content of the DNA is $39 \mathrm{~mol} \%$.

Differentiated from other species in the genus by DNA/DNA homology studies and by electrophoretic mobilities of soluble cellular proteins.

Type strain: ATCC $33540(=$ VPI 12140 from Rogosa PV1, guinea pig mouth).

Comments. According to our results, most of the human oral isolates belong to $V$. atypica, $V$. parvula, or $V$. dispar. Of the human strains examined serologically, most belonged to serogroup VI of $V$. atypica.

\section{ACKNOWLEDGMENTS}

This work was supported by Public Health Service grants DE 05218, DE 05139, GM 14604, and AI 15244 from the National Institutes of Health.

\section{REPRINT REOUESTS}

Address reprint requests to: Dr. J. L. Johnson, Department of Anaerobic Microbiology, Virginia Polytechnic Institute and State University, Blacksburg, VA 24061.

\section{LITERATURE CITED}

1. Chelm, B. K., and R. B. Hallick. 1976. Changes in the expression of the chloroplast genome Euglena gracilis during chloroplast development. Biochemistry 15:593599.

2. Crosa, J. H., D. J. Brenner, and S. Falkow. 1973. Use of single-strand-specific nuclease for analysis of bacterial and plasmid deoxyribonucleic acid homo- and heteroduplexes. J. Bacteriol. 115:904-911.

3. Cummins, C. S., and J. L. Johnson. 1971. Taxonomy of the clostridia: wall composition and DNA homologies in Clostridium butyricum and other butyric acid-producing clostridia. J. Gen. Microbiol. 67:33-46.
4. Foubert, E. L., Jr., and H. C. Douglas. 1948. Studies on the anaerobic micrococci. I. Taxonomic considerations. J. Bacteriol. 56:25-34.

5. Holdeman, L. V., E. P. Cato, and W. E. C. Moore (ed.). 1977. Anaerobe laboratory manual, 4th ed. Virginia Polytechnic Institute and State University, Blacksburg.

6. Johnson, J. L. 1973. Use of nucleic-acid homologies in the taxonomy of anaerobic bacteria. Int. J. Syst. Bacteriol. 23:308-315.

7. Johnson, J. L. 1978. Taxonomy of the Bacteroides. I. DNA homologies among Bacteroides fragilis and other saccharolytic Bacteroides species. Int. J. Syst. Bacteriol. 28:245-256.

8. Johnson, J. L. 1980 . Specific strains of Bacteroides species in human fecal flora as measured by deoxyribonucleic acid homology. Appl. Environ. Microbiol. 39:407-413.

9. Johnson, J. L., and C. S. Cummins. 1972. Cell wall composition and deoxyribonucleic acid similarities among the anaerobic coryneforms, classical propionibacteria, and strains of Arachnia propionica. J. Bacteriol. 109:10471066

10. Johnson, J. L., C. F. Phelps, C. S. Cummins, J. London, and F. Gasser. 1980. Taxonomy of the Lactobacillus acidophilus group. Int. J. Syst. Bacteriol. 30:53-68.

11. Kafkewitz, D., and E. A. Delwiche. 1969. Utilization of Dribose by Veillonella. J. Bacteriol. 98:903-907.

12. Kafkewitz, D., and E. A. Delwiche. 1972. Ribose utilization by Veillonella alcalescens. J. Bacteriol. 109:11441148 .

13. Langford, G. C., Jr., J. E. Faber, Jr., and M. J. Pelczar. 1950. The occurrence of anaerobic gram-negative diplococci in the normal human mouth. J. Bacteriol. 59:349356.

14. Marmur, J. 1961. A procedure for the isolation of deoxyribonucleic acid from microorganisms. J. Mol. Biol. 3:208-218.

15. Marmur, J., and P. Doty. 1962. Determination of the base composition of deoxyribonucleic acid from its thermal denaturation temperature. J. Mol. Biol. 5:109-118.

16. Moore, W. E. C., D. E. Hash, L. V. Holdeman, and E. P. Cato. 1980. Polyacrylamide slab gel electrophoresis of soluble proteins for studies of bacterial floras. Appl. Environ. Microbiol. 39:900-907.

17. Prévot, A. R. 1933. Études de systématique bactérienne. I. Lois generales. II. Cocci anaérobies. Ann. Sci. Nat. Bot. 15:23-260.

18. Rogosa, M. 1964. The genus Veillonella. I. General cultural, ecological, and biochemical considerations. J. Bacteriol. 87:162-170.

19. Rogosa, M. 1965. The genus Veillonella. IV. Serological groupings and genus and species emendations. J. Bacteriol. 90:704-709.

20. Rogosa, M. 1974. Gram-negative anaerobic cocci, p. 445 447. In R. E. Buchanan and N. E. Gibbons (ed.), Bergey's manual of determinative bacteriology, 8 th ed. The Williams \& Wilkins Co., Baltimore.

21. Rogosa, M., and F. S. Bishop. 1964. The genus Veillonella. II. Nutritional studies. J. Bacteriol. 87:574-580.

22. Rogosa, M., and F. S. Bishop. 1964. The genus Veillonella III. Hydrogen sulfide production by growing cultures. J. Bacteriol. 88:37-41.

23. Rogosa, M., M. I. Krichevsky, and F. S. Bishop. 1965. Truncated glycolytic system in Veillonella. J. Bacteriol. 90:164-171.

24. Skerman, V. B. D., V. McGowan, and P. H. A. Sneath (ed.). 1980. Approved lists of bacterial names. Int. J. Syst. Bacteriol. 30:224-420.

25. Veillon, A., and M. M. Zuber. 1898. II. Recherches sur quelques microbes strictement anaérobies et leur role en pathologie. Arch. Med. Exp. 10:517-545.

26. Yoshimura, F., N. Kasai, B. Sugawara, and T. Suzuki. 1980. Acetate kinase in the genus Veillonella: effect of succinate, serological cross-reactivity, and separation by electrophoresis. J. Bacteriol. 141:1312-1319. 